Creative Commons User License: CC BY-NC-ND

Abstracted by: EBSCOhost, Electronic Journals Service (EJS), Google Scholar, Journal Seek, Scientific Commons,

Food and Agricultural Organization (FAO), CABI and Scopus
Journal of Agricultural Extension

Vol. 23 (4) October, 2019

ISSN(e): 24086851; ISSN(Print); 1119944X

http://journal.aesonnigeria.org

http://www.ajol.info/index.php/jae

Email: editorinchief@aesonnigeria.org

\title{
Differences in Food Crop Diversification between Male and Female \\ Smallholder Farmers in Kwara State, Nigeria \\ https://dx.doi.org/10.4314/jae.v23i4.1
}

\section{Daudu, Abdulrazaq Kamal}

Department of Agricultural Extension and Rural Development,

University of Ilorin, Ilorin, Nigeria

Email: daudu.ak@unilorin.edu.ng

$+2348032853580$

\section{Oladipo, Felix Olayinka}

Department of Agricultural Extension and Rural Development, University of Ilorin, Ilorin, Nigeria

Email: felixoladipo5@gmail.com

$+2348032275101$

\section{Olatinwo, Latifat Kehinde}

Department of Agricultural Economics and Extension,

Kwara State University, Malete, Nigeria

Email: latifatolatinwo@hotmail.com

+2348063134705

\section{Kareem, Oyedola Waheed}

Department of Agricultural Extension and Rural Development,

University of Ilorin, Ilorin, Nigeria

Email: kareem.ow@unilorin.edu.ng

$+2348032151063$

\section{Dolapo, Tawakalitu Abiola}

Department of Agricultural Extension and Rural Development, University of Ilorin, Ilorin, Nigeria

Email: dolapo.ta@unilorin.edu.ng $+2348060161228$

\section{Abstract}

The study assessed food crop diversification among smallholder male and female farmers in Kwara State, Nigeria. A two-stage sampling technique was used to select 384 respondents disaggregated into 197 males and 187 females. Percentages, mean and standard deviation and chart were used for data analysis. Findings showed that the mean number of food crop grown by male farmers was 4.8 while that of female was 3.3 and most $(51.4 \%$ and 49.3\%) of male and female farmers growing 3 and 5 crops at a time respectively. Findings from crop diversification index showed that most of male farmers fall into high diversification group (0.60-0.70) while most female farmers were moderately (0.50-0.60) diversified. It further shows that education, farm size and access to farm machineries and credit positively and significantly influence the extent of crop diversification among male and female smallholder farmers $(P \geq 0.05)$. Male farmers were found to be highly diversified compared to female farmers. Extension education toward bridging 
Creative Commons User License: CC BY-NC-ND

Abstracted by: EBSCOhost, Electronic Journals Service (EJS),

Google Scholar, Journal Seek, Scientific Commons,

Food and Agricultural Organization (FAO), CABI and Scopus
Journal of Agricultural Extension

Vol. 23 (4) October, 2019

ISSN(e): 24086851; ISSN(Print); 1119944X

http://journal.aesonnigeria.org

http://www.ajol.info/index.php/iae

Email: editorinchief@aesonnigeria.org

gap in male and female farmers' literacy, skills and training on crop diversification should be promoted.

Keywords: Crop diversification, food crop, herfindahl index, Tobit regression, smallholder farmers

\section{Introduction}

Food crop production remains a central aim of most smallholder farmers that dominated Nigeria agricultural sector. Although Nigeria has a huge potential for agricultural development, but hunger has characterized the majority of its population due to low agricultural production. According to Maurice et al. (2013) food crop production in Nigeria is dominated by small-scale farmers who cultivate between 0.1 - 5.99 hectares and produce about $85-90 \%$ of the total foods consumed in the country. These farmers are constrained by inadequate finance to expand production, hence rely on personal savings for their agricultural operations. These challenges affect individual farmers and put the household welfare of the farmer at danger or at risk. This risk encourages smallholder farmers to engage in cultivation of more crops/diversification in to production of other crops which are expected to increase income and improve their livelihood.

Crop diversification has been described as a strategy to maximize the use of land, water and other resources and for the overall agricultural development in the country. It provides the farmers with viable options to grow different crops on their land. Sati (2012), asserts that the diversification of agriculture is the outcome of the natural demands as initially the farmers are cultivating their land for the subsistence of their livelihood but as the population increases and per capita land decreases the diversification of agriculture begins. He points out that farmer's decisions are influence by environmental, socioeconomic, and cultural factors as well as political climate. Generally, to increase farmers' income, to curtail unemployment and stabilize the income flow, diversification of crops emerges as a major important strategy. Kumar (2014) explains the pattern of agriculture diversification in India and observes that agriculture production is shifting from traditional subsistence agriculture to high value products. He further states that the major force behind the shift in production is the change in consumption pattern and suggests that there is a need for integration of production with market to boost the agriculture diversification. Also, Bowman and Zilberman (2013) noted the factors influencing the diversified crop farming system and provide the economic perspective on the factors which make diversified farming system economically attractive to farmers. They suggested that in order for crop diversification to thrive; a number of structural changes are needed in the farming system.

Daudu, Oladipo and Kayode (2017), noted that smallholder women farmers are less involved in soil fertility management practices that are critical to food crop production. They are also confronted with problems than their men counterparts in terms of access to credits, resource inputs, and extension information in Kwara State, Nigeria. Since, both men and women are responsible for production of food 
Creative Commons User License: CC BY-NC-ND

Abstracted by: EBSCOhost, Electronic Journals Service (EJS), Google Scholar, Journal Seek, Scientific Commons,

Food and Agricultural Organization (FAO), CABI and Scopus
Journal of Agricultural Extension

Vol. 23 (4) October, 2019

ISSN(e): 24086851; ISSN(Print); 1119944X

http://journal.aesonnigeria.org

http://www.ajol.info/index.php/iae

Email: editorinchief@aesonnigeria.org

crops in Nigeria, men have always been seen as dominants and this assumption undermines women's participation in agricultural activities.

The general view of crop diversification among male and female farmers is a transition from traditionally grown less remunerative crops to more remunerative crops. But their participation and practices varies across different food crops. This study therefore, sought to assess the differences in food crop diversification among male and female smallholder farmers in Kwara State, Nigeria. Specifically, to:

i. determined the extent of crop diversification among male and female smallholder food crop farmers; and

ii. examined the factors influencing crop diversification among the male and female respondents.

\section{Methodology}

The study was carried out in Kwara State, Nigeria. It is one of the six states in North central geopolitical zone of Nigeria. It is located between latitude $8^{\circ} 5^{\prime}-10^{\circ} 4^{\prime} \mathrm{N}$ and longitude $4^{\circ} 55^{\prime}-6^{\circ} 5^{l} \mathrm{E}$ covering an estimated land area of $32,500 \mathrm{~km}$ with a projected population of about 3.2 million (National Population Commission, 2016). The climate of the state is characterized by wet and dry seasons, with wet season starting from about the end of march and lasts till October while, dry seasons begins in November and ends early March. The total annual rainfall ranges between 1000 $\mathrm{mm}$ to $1,500 \mathrm{~mm}$. The minimum temperature ranges between 21.1 and 25.0 degree Celsius while maximum temperature ranges between 30 and 35 degree Celsius. The vegetation of the state is derived guinea savannah with large expense of arable land and rich fertile soils (KWSMANR, 2016).

A two-stage sampling procedure was used to select the respondents from 183,019 smallholder crop farmers for the study. First stage involved a proportionate random sampling technique of $0.2 \%$ of male and female farmers from the list of registered smallholder farmers $(183,019)$ from Kwara State Agricultural Development Programme (KwADP) making a total of 384 respondents (i.e. 197 males and 187 females) were used as sample size.

Data were collected with the aid of structured questionnaire and interview schedule on farmers' socioeconomic variables such as age, educational level, household size, farming experience extension contact, and various food crops grown and farming practices employed were measured accordingly and analysed using charts, means and standard deviation, percentages and regression.

The extent of crop diversification among male and female smallholder farmers was determined using crop diversification index used by Swades and Shyamal (2012). Crop diversification (CD), a potentially endogenous variable, is estimated by subtracting the Herfindahl index $(\mathrm{HI})$ from one $(1-\mathrm{HI})$, where $\mathrm{HI}$ as used by Swades and Shyamal (2012) was calculated as follows:

$$
\begin{gathered}
H I=\sum_{i=0}^{n} P_{i}^{2} \\
P_{i}=\frac{A_{i}}{\sum_{i=0}^{n} A_{i}} .
\end{gathered}
$$


Where $\mathrm{HI}=$ Herfindahl index

$P_{i}=$ Proportion of crop;

$A_{i}=$ Area under crop;

$\sum_{i=0}^{n} A_{i}=$ Total cropped area;

$A_{i}=1,2,3, \ldots$ (Number of crops considered).

Therefore, the extent of crop diversification can be given as:

$$
\text { Crop Diversification Index }=1-\sum_{i=0}^{n} P_{i}^{2}
$$

In this case, we estimated crop diversification as an index of concentration that ranges between 0 (specialization) and 1 (complete diversification). Any value above zero signifies diversification. Thus, crop diversification index could be thus categorized as follows: Very high $=0.70-1.0$, High $=0.60-0.70$, Medium $=0.50-0.60$, Low $=0.40-0.50$ and Very low $=0-0.40$.

\section{Results and Discussion}

\section{Crops Grown by Smallholder Farmers}

Table 1 shows various food crops being grown by smallholder farmers in the study area. Findings revealed that the majority (74.6\%) of male farmers and some $32.8 \%$ of female farmers grow sorghum. This finding shows that there are more male farmers growing sorghum compare with their female counterparts. Also, all (100\%) of male farmers and the majority (83.4\%) of female farmers grow cassava, 93.1 and $39.1 \%$ of male and female farmers respectively grow yam while, most $(79.6 \%)$ of female farmers grow vegetable crops with only $36.4 \%$ of male farmers follow suit. Further results in figure 5 showed that the percentage of male farmers involved in growing crops such as cowpea (56.8 and 18.3\%), groundnuts (48.2 and $12.6 \%$ ), sweet potato (21.3 and $1.9 \%)$, rice (26.4 and $8.8 \%)$ and soybean ( 42.5 and $22.6 \%$ ) is higher than their female counterparts in the study area.

Table 1: Various crops grown by male and female farmers

\begin{tabular}{lcc}
$\begin{array}{c}\text { Food crops grown } \\
\text { by respondents }\end{array}$ & $\begin{array}{c}\text { Male }(\mathbf{n = 1 9 7 )} \\
\text { Percentage }(\%)^{*}\end{array}$ & $\begin{array}{c}\text { Female }(\mathbf{n}=\mathbf{1 8 7}) \\
\text { Percentage }(\%)^{*}\end{array}$ \\
Maize & 100 & 100 \\
Sorghum & 74.6 & 32.8 \\
Cassava & 100 & 83.4 \\
Yam & 93.1 & 39.1 \\
Vegetables & 36.4 & 79.6 \\
Cowpea & 56.8 & 18.3 \\
Groundnuts & 48.2 & 12.6 \\
Sweet potato & 21.3 & 1.9 \\
Rice & 26.4 & 8.8 \\
Soy bean & 42.5 & 22.6 \\
\hline
\end{tabular}

Source: Field survey (2018) *Multiple response 
Creative Commons User License: CC BY-NC-ND

Abstracted by: EBSCOhost, Electronic Journals Service (EJS), Google Scholar, Journal Seek, Scientific Commons,

Food and Agricultural Organization (FAO), CABI and Scopus
Journal of Agricultural Extension

Vol. 23 (4) October, 2019

ISSN(e): 24086851; ISSN(Print); 1119944X

http://journal.aesonnigeria.org

http://www.ajol.info/index.php/iae

Email: editorinchief@aesonnigeria.org

Results in Table 2 show that the mean number of food crop grown by male farmers was 4.8 while that of female was 3.3. This suggests that male farmers grown large number food crops than their female counterparts in the study area. This is an indication that smallholder male farmers are involved more in the production food crops compare to smallholder female farmers in the study area. Also, findings revealed that none $(0 \%)$ of the male farmers and only $6.7 \%$ of female farmers practicing sole/mono cropping system with most (51.4 and $49.3 \%$ ) of male and female farmers growing 5 and 3 crops at a time respectively.

Table 2: Number of crops grown by male and female farmers

\begin{tabular}{ccc}
\hline $\begin{array}{c}\text { Number of food crops } \\
\text { grown by respondents }\end{array}$ & $\begin{array}{c}\text { Male }(\mathbf{n}=197) \\
\text { Percentage }\end{array}$ & $\begin{array}{c}\text { Female }(\mathbf{n}=187) \\
\text { Percentage }\end{array}$ \\
Sole & 0 & 6.7 \\
2 & 0.8 & 19.8 \\
3 & 6.9 & 49.3 \\
4 & 26.6 & 21.5 \\
5 & 51.4 & 2.5 \\
$>5$ & 14.3 & 0.2 \\
Mean & 4.8 & 3.3 \\
\hline
\end{tabular}

Source: Field survey (2018)

\section{Extent of Crop Diversification among Smallholder Farmers by Gender}

The results in Figure 1 show the extent of crop diversification among male and female smallholder farmers in the study area. It was revealed that 0.2 and $4.1 \%$ of male and female farmers, respectively had crop diversification index of less than 0.40 and are categorized as very low. Also, about $29.2 \%$ of male farmers and most $(58.9 \%)$ of female farmers had crop diversification index of between 0.50 and 0.60 and are classified as medium. Results show that most (54.3\%) of male farmers and $23.4 \%$ of female farmers with diversification index of 0.6 to 0.70 were highly diversified their crop production enterprise, while 12.9 and $2.8 \%$ of male and female farmers respectively were categorized as very high diversification and lies above 0.70 diversification index. This finding suggests that most of male farmers fall into high diversification group while most female farmers were moderately diversified. The high level of crop diversification as observed in male category might be as a result of taking less risk by cultivating several food crops together which implied that the male farmers are aware of the benefits inherent in crop diversification and therefore, their knowledge of these advantages would likely to be from past farming experiences. 
Creative Commons User License: CC BY-NC-ND

Abstracted by: EBSCOhost, Electronic Journals Service (EJS), Google Scholar, Journal Seek, Scientific Commons,

Food and Agricultural Organization (FAO), CABI and Scopus
Journal of Agricultural Extension

Vol. 23 (4) October, 2019

ISSN(e): 24086851; ISSN(Print); 1119944X

http://journal.aesonnigeria.org

http://www.ajol.info/index.php/jae

Email: editorinchief@aesonnigeria.org

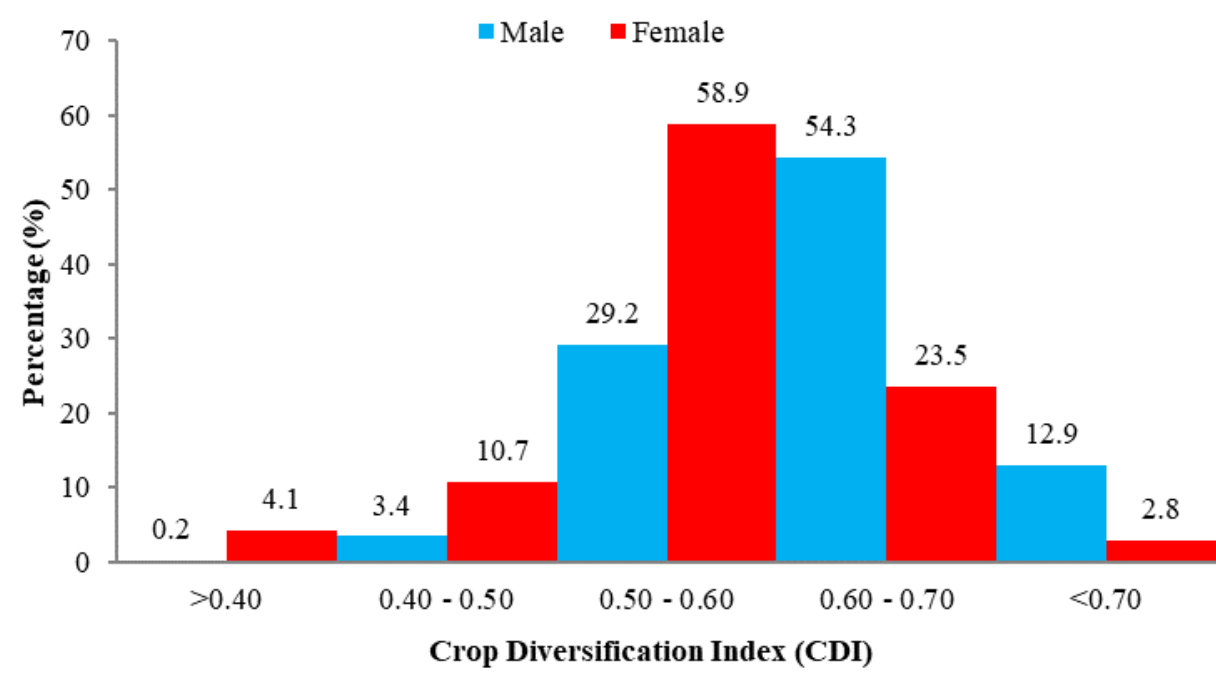

Fig. 1: Distribution of the crop diversification index among smallholder farmers by gender

Source: Field survey (2018)

Decision: $>0.70=$ Very high, $0.60-0.70=$ High, $0.50-0.60=$ Medium, $0.40-0.50=$ Low, $<0.40=$ Very low

\section{Factors Influencing Crop Diversification among the Male and Female Smallholder Farmers}

The Table 3 present the disaggregated crop diversification determinant factors of male and female smallholder farmers in the study area. The log likelihood for the fitted model for male and female farmers was 10.326 and 13.564 and the chi-square was 29.7 and 34.3 respectively and reasonably significant at $5 \%$ level. Thus the overall model is significant and the explanatory variables used in the model are collectively able to explain the variations in farm crop diversification. Age was negatively significant for the male farmers at $5 \%$ and it implies that a unit increase in age of male farmers will have negative effect on their crop diversification by 0.065 . 
Creative Commons User License: CC BY-NC-ND

Abstracted by: EBSCOhost, Electronic Journals Service (EJS),

Google Scholar, Journal Seek, Scientific Commons,

Food and Agricultural Organization (FAO), CABI and Scopus
Journal of Agricultural Extension

Vol. 23 (4) October, 2019

ISSN(e): 24086851; ISSN(Print); 1119944X

http://journal.aesonnigeria.org

http://www.ajol.info/index.php/iae

Email: editorinchief@aesonnigeria.org

Table 3: Factors influencing crop diversification among male and female smallholder farmers

\begin{tabular}{|c|c|c|c|c|}
\hline \multirow{2}{*}{ Factors } & \multicolumn{2}{|c|}{ Male $(n=197)$} & \multicolumn{2}{|c|}{ Female $(n=187)$} \\
\hline & Coefficient & Standard Error & Coefficient & Standard Error \\
\hline Age & $-0.065^{\star *}$ & 0.522 & 0.264 & 0.151 \\
\hline Educational level & $0.466^{* * *}$ & 0.146 & $2.574^{\star *}$ & 0.437 \\
\hline Household size & $0.698^{*}$ & 0.331 & $3.448^{* *}$ & 0.525 \\
\hline $\begin{array}{l}\text { Farm size } \\
\text { Access to farm }\end{array}$ & $0.014^{* *}$ & 0.064 & $0.227^{* *}$ & 0.206 \\
\hline machineries & $0.294^{* * *}$ & 0.063 & $0.168^{* * *}$ & 0.192 \\
\hline Extension contact & $1.435^{\star}$ & 0.647 & 3.621 & 2.489 \\
\hline Access to credit & $1.219^{*}$ & 0.586 & $0.369^{*}$ & 0.318 \\
\hline Constant & 2.835 & 3.244 & 2.178 & 4.469 \\
\hline Log likelihood & \multicolumn{2}{|c|}{10.326} & \multicolumn{2}{|c|}{13.564} \\
\hline LR Chi2 (4) & \multicolumn{2}{|c|}{29.7} & \multicolumn{2}{|c|}{34.3} \\
\hline Prob>Chi2 & \multicolumn{2}{|c|}{0.0004} & \multicolumn{2}{|c|}{0.0006} \\
\hline Pseudo R ${ }^{2}$ & \multicolumn{2}{|c|}{0.4461} & \multicolumn{2}{|c|}{0.6743} \\
\hline
\end{tabular}

Experience is a function of age, increase in age may suggest an increase in experience and this mean the farmer may become more diversified. This agrees with the findings of Ojo et al. (2014) who also found that a farmer's risk bearing ability reduces as his/her age increases. While in female category, age was not a significant factor determining their crop diversification practices, this suggests that female farmers at any level of age may engage in crop diversification in order to take more risk, earn more income and improve their living conditions. The level of education was positive and significant for both male and female smallholder farmers at $1 \%$ and $5 \%$ respectively. This finding suggests that the increase in educational level of both categories of farmers will increase their risk taken on several profitable crops since education strengthens the creative thinking and knowledge of human being. Any increase in educational level of both male and female farmers will increase their crop diversification by $0.47 \%$ and $2.57 \%$ for the male and female farmers respectively. The results show that household size for both male and female farmers were positive and significant at $10 \%$ and $5 \%$ respectively, suggesting that an increase in the household size of both male and female farmers will increase their extent of crop diversification by $0.70 \%$ and $3.45 \%$ respectively. The implication is that large household would provide more labour for the crop production activities of the farmers especially for those that rely heavily on family labour.

Results show that farm size was positive and significant in both categories of farmers at $5 \%$. This suggests size of farm land increases the probability that a farmer will involve in crop diversification - implying that there is a direct relationship between farm size and crop diversification. The implication is that an increase in the farm size will no doubt better enable a farmer to diversify. With the extra landholding, the farmer can decide how many crops to grow based on his or her production decisions. This also, in line Oladipo, Daudu and Kuye (2017) in which they reported 
Creative Commons User License: CC BY-NC-ND

Abstracted by: EBSCOhost, Electronic Journals Service (EJS),

Google Scholar, Journal Seek, Scientific Commons,

Food and Agricultural Organization (FAO), CABI and Scopus
Journal of Agricultural Extension

Vol. 23 (4) October, 2019

ISSN(e): 24086851; ISSN(Print); 1119944X

http://journal.aesonnigeria.org

http://www.ajol.info/index.php/iae

Email: editorinchief@aesonnigeria.org

that the more access to additional farmland that a farmer has, the more he or she will be able to engage in crop production.

Access to farm machineries significantly determines the probability of any category of farmers to engage in crop diversification. The probability of a either male or female farmer who uses farm machineries participating in crop diversification was 0.29 and $0.17 \%$ for male and female farmers respectively higher than for a male or female who does not use farm machinery. Thus a farmer who uses farm machinery will more likely diversify his or her crops because using farm machinery reduces the drudgery of land preparation, reduces the requirement for manual labour, and enables the exploitation of a larger land area compared to using a hand hoe.

The coefficient of contact with change agents was positive in male category; however significant at $10 \%$ in determining crop diversification among the male farmers. This revealed that, since most of the male farmers were mainly involved in crop farming activities, contact with extension agents is highly essential in transferring new innovation to the farmers especially on best practices so as to increase productivity, income and thus better their standard of living. In female category, extension contact was also positive but not significant at any degree. This may be due to inadequate number agricultural extension agents to relate and change the life of female farmers through best crop diversification practices in the study area. Access to credit facilities was also positive and significant in determining the extent of crop diversification among male and female farmers at $10 \%$ level. This suggests that access to credit among the two categories of farmers will increase the probability that male or female farmers will engage in productive and profitable mixed cropping system and thereby raise their income level.

\section{Conclusion and Recommendations}

Male and female smallholder farmers grow different food crops in effort to earn more income and improve their livings. However, male farmers were found to be highly diversified compare to female farmers. It further shows that level of education, farm size and access to farm machineries and credit positively and significantly influence the extent of crop diversification among male and female smallholder farmers in the study area. Extension education toward bridging gap in farmers' literacy, skills and training on crop diversification should be promoted. This is mainly because of the advantages that come with diversified cropping systems which largely reduce risks of crop production, gives more income options to the farmer, and makes production on the farm more stable. Also, special attention should be given to female farmers to improve their participation in crop diversification that will enhance building resilience for their poor income and ensure food security.

\section{References}

Bowman, M. S. and Zilberman, D., (2013), Economic factors affecting diversified farming systems, Ecology and Society, Vol. 18, No. 1, pp. 33-47.

Daudu, A.K., Oladipo, F.O and Kayode, A.O (2017): Gender capacity building needs 
Creative Commons User License: CC BY-NC-ND

Abstracted by: EBSCOhost, Electronic Journals Service (EJS), Google Scholar, Journal Seek, Scientific Commons,

Food and Agricultural Organization (FAO), CABI and Scopus
Journal of Agricultural Extension

Vol. 23 (4) October, 2019

ISSN(e): 24086851; ISSN(Print); 1119944X

http://journal.aesonnigeria.org

http://www.ajol.info/index.php/jae

Email: editorinchief@aesonnigeria.org

on soil fertility management practices among smallholder arable crop farmers in Kwara State, Nigeria. Journal of the Saudi Society of Agricultural Sciences. Available online at http://dx.doi.org/10.1016/j.jssas.2017.06.003

Kumar P., (2014), Agriculture diversification in India, Indian Journal of Applied Research, Vol. 4, No. 8, pp. 648-652

Oladipo, F.O, Daudu, A.K., and Kuye, M.M (2017): Assessment of poverty alleviation strategies used by rural farming households in Ondo State, Nigeria. International Journal of Agricultural Science Research and Technology in Extension and Education Systems. Vol. 7, Issue 2, Page 73-78. Available at http://ijasrt.iaushoushtar.ac.ir/volume 113661.html

Kwara State Ministry of Agriculture and Natural Resource, (2016)

Report of the Kwara State farmers' census

Maurice, D. C., Onu, J. I., Adebayo, E. F and Garba, A., (2013). Optimal production plan and resource allocation among small-scale farmers in some selected Local Government Areas of Adamawa State, Nigeria. Journal of Technology and Education Research (JOTER), 6, (2), 47-57.

National Population Commission (2016): National Population Census. The Projected Population for Nigerian States.

Ojo, M. A., Ojo, A. O., Odine, A. I., \& Ogaji, A. (2014): Determinants of crop diversification among small - scale food crop farmers in north central, Nigeria. Production Agriculture and Technology Journal, 10(2), 1-11

Sati, V. P (2012): Agricultural diversification in the Garhwal Himalaya: A Spatio Temporal Analysis, Sustainable Agriculture Research, Vol. 1, No. 1, 77-86.

Swades P. and K. Shyamal (2012): Implications of the methods of agricultural diversification in reference with malda district: drawback and rationale. International Journal of Food, Agriculture and Veterinary Sciences 2 (2): 97- 105 http://www.cibtech.org/jfav.htm.

United Nations Population Fund (2013): Gender Equality: A Cornerstone of Development. Retrieved in 2013 from http://www. unfpa.org/genderGoogle Scholar 